\title{
Structural and vibrational behaviour of pyromorphite-vanadinite solid solution series
}

\author{
Urszula Solecka, Tomasz Bajda, Justyna Topolska, Maciej Manecki
}

AGH University of Science and Technology, Faculty of Geology, Geophysics and Environmental Protection, Department of Mineralogy, Petrography and Geochemistry; al. Mickiewicza 30, 30-059 Krakow, Poland; e-mail: ujanicka@agh.edu.pl

(C) 2015 Authors. This is an open access publication, which can be used, distributed and reproduced in any medium according to the Creative Commons CC-BY 4.0 License requiring that the original work has been properly cited.

Pyromorphite $\mathrm{Pb}_{5}\left(\mathrm{PO}_{4}\right)_{3} \mathrm{Cl}$ and vanadinite $\mathrm{Pb}_{5}\left(\mathrm{VO}_{4}\right)_{3} \mathrm{Cl}$ belong to the apatite supergroup. They are secondary minerals formed in the oxidation zones of lead ore deposits. Both crystallize in hexagonal symmetry with the space group $\mathrm{P}_{3} / \mathrm{m}$ (Dong et al. 2002). The crystal structure of these two minerals allows to accommodate both metal cations and anionic complexes. It is the reason, why pyromorphite and vanadinite forms solid solution series. Isovalent replacement of $\mathrm{P}$ with $\mathrm{V}$ is one of the most common anionic substitution.

Lead apatites are one of the least soluble along apatites group minerals and characterized by high thermal stability (Dong et al. 2002, Flis et al. 2011). Characteristic properties of apatite structure cause that these minerals are successfully used in many fields, especially for the immobilization of toxic waste and lead-contaminated soil (Ma et al. 1993, Chen et al. 1997, Dong et al. 2002, Kim et al. 2005). So far, pyromorphite and mimetite are the most known and used for the immobilization of lead. Pyromorphite and mimetite are isostructural with vanadinite, therefore it has been predicted that this mineral is also important for the environment. Accordingly, the aim of this study was to characterize of the pyromorphite-vanadinite solid solution series. This research presents systematic changes in the structure of these minerals.

Pure pyromorphite and vanadinite and minerals with intermediate compositions $\mathrm{Pb}_{5}\left(\mathrm{TO}_{4}\right)_{3} \mathrm{Cl}$, where $\mathrm{T}=\mathrm{P}+\mathrm{V}$, of various $\mathrm{P} / \mathrm{V}$ ratios were synthesized from aqueous solutions at $298 \mathrm{~K}$ and $\mathrm{pH}=3.5$. Synthetic solids were analyzed by X-Ray diffraction (XRD), infrared absorption spectroscopy (FTIR) and Raman spectroscopy.

Based on the X-Ray analysis, it was found that synthetic precipitates represent homogeneous phases of pyromorphite and vanadinite, which have intermediate chemical composition. Diffraction peaks of pyromorphite-vanadinite solid solution series were shifted due to replacement of $\mathrm{PO}_{4}$ by $\mathrm{VO}_{4}$. Replacement of $\mathrm{PO}_{4}$ by $\mathrm{VO}_{4}$ anions is causing changes in the structure of apatite and hence these shifts. Unit cell parameters of studied solid solutions show a linear variation.

In the FTIR and Raman spectra of pyromorphite-vanadinite solid solutions series, the bands which are characteristic for vibrations of $\mathrm{P}-\mathrm{O}$ bonds of the $\mathrm{PO}_{4}$ tetrahedra as well as vibrations of $\mathrm{V}-\mathrm{O}$ bonds of the $\mathrm{VO}_{4}$ tetrahedra appeared. Analysis of MidIR spectra and Raman spectra also allowed observing correlation between the band positions and the extent of the anionic substitution among the studied series.

The structure of pyromorphite and vanadinite is generally similar, although the two minerals vary in chemical composition. This variability results probably from the properties of individual ions.

The project was financed with resources of the $\mathrm{Na}$ tional Science Centre, Poland, granted based on decision no. DEC-2013/09/N/ST10/00677. 


\section{REFERENCES}

Chen X., Wright J.V., Conca J.L. \& Peurrung L.M., 1997. Evaluation of heavy metal remediation using mineral apatite. Water, Air and Soil Pollution, 98, 57-78.

Dong Z., White T.J., Wei B. \& Laursen K., 2002. Model Apatite Systems for the Stabilization of Toxic Metals: I, Calcium Lead Vanadate. Journal of the American Ceramic Society, 85, 10, 2515-2522.
Flis J., Manecki M. \& Bajda T., 2011. Solubility of pyromorphite $\mathrm{Pb}_{5}\left(\mathrm{PO}_{4}\right)_{3} \mathrm{Cl}$-mimetite $\mathrm{Pb}_{5}\left(\mathrm{AsO}_{4}\right)_{3} \mathrm{Cl}$ solid solution series. Geochimica et Cosmochimica Acta, 75, 1858-1868. Kim J.Y., Dong Z. \& White T.J., 2005. Model Apatite Systems for the Stabilization of Toxic Metals: II, Cation and Metalloid Substitutions in Chlorapatites. Journal of the American Ceramic Society, 88, 5, 1253-1260.

Ma Q.Y., Traina S.J, Logan T.J. \& Ryan J.A., 1993. In Situ Lead Immobilization by Apatite. Environmental Science and Technology, 27, 1803-1810. 